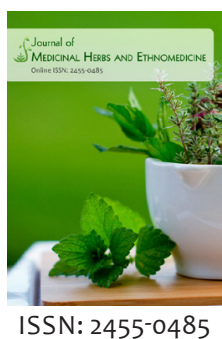

Received: January 21, 2020 Accepted: May 22, 2020 Published: June 26, 2020

*Corresponding Author: O. D. Omodamiro Email:majekdamiro@yahoo. com

\section{Evaluation of antioxidant potential and anti-diabetic effect of ethanol seed extract of Garcinia kola (Bitter Kola) in albino rat}

\author{
O. D. Omodamiro*, O. Ajah, C. Ewa-ibe \\ Pharmacology Unit, Department of Biochemistry, Michael Okpara University of Agriculture, Umudike, Umuahia \\ Abia State, Nigeria
}

\begin{abstract}
The medicinal properties of plants have been investigated in the recent scientific world because of their potent antioxidant activities, mild side effects and economic viability. This study evaluated the antioxidant property and antidiabetic effect of ethanol seed extract of G. kola (bitter kola) on alloxan induced diabetic albino rats. The in-vitro antioxidant assay was done using standard methods. Thirty (36) albino rats were used for the in-vivo study and fasted for 16-18hours and thereafter induced diabetes with $150 \mathrm{mg} / \mathrm{kg}$ b.w. of alloxan monohydrate via intraperitoneal injection. The animals were divided into six groups of six (6) rats each. Group A was the normal control, group B was the positive control (treated with $5 \mathrm{mg} / \mathrm{kg}$ b.w of glabeclamide), Group C was the negative control (untreated) and groups D through F were administered $500 \mathrm{mg} / \mathrm{kg}, 250 \mathrm{mg} / \mathrm{kg}$ and $125 \mathrm{mg} / \mathrm{kg}$ of the extract respectively. The results showed $49.70 \%$ reduction in blood glucose level of the $500 \mathrm{mg} / \mathrm{kg}$ extract treated group compared to the positive control $(45.03 \%)$ on the day 7 . The antioxidant results showed a significant $(\mathrm{p}<0.05)$ dose dependent increase in its ability to scavenge free radicals. The results of this study suggested the use of G. kola seed for the treatment of free radical mediated diseases and management of diabetes.
\end{abstract}

KEYWORDS: Diabetes, Garcinia kola, antioxidant, medicinal plant, effect

\section{INTRODUCTION}

Diabetes mellitus (DM) is a metabolic disorders in which there are high blood sugar levels over a prolonged period $[1,2]$. The prevalence of diabetes is $8.5 \%$ among adults and serious longterm complications of this disease include cardiovascular disease, stroke, chronic kidney disease, foot ulcers, and damage to the eyes $[3,4,5,6]$.

Plant-derived substances have recently attracted great research interest owing to their versatile applications [7]. Specifically, medicinal plants are the richest bio-resource of drugs of traditional systems of medicine, modern medicines, nutraceuticals, food supplements, folk medicines, pharmaceutical intermediates and chemical entities for synthetic drugs [7]. This is due to the presence of secondary metabolites which accumulate in the various parts of these plants conferring on them their pharmacological relevance. Garcinia kola is widely consumed habitually and used as traditional remedy for various diseases in Nigeria.
Garcinia kola commonly called bitter kola belongs to the family Guttiferae and found mainly in the tropical rain forest region of Central and West Africa [8]. It is predominant in rainforest belt of southern Nigeria [9]. The seeds are edible and are consumed as adjuvant to the true kola (Cola nitida) and for medicinal purposes [10]. Garcinia kola plant is a wonder plant because every part of it has been found to be of medicinal importance. Garcinia kola is used in folklore remedies for the treatment of ailments such as liver disorders, diarrhoea, laryngitis, bronchitis and gonorrhoea[11]. The seed is masticatory and used to prevent and relieve chest colds and cough and can as well be used to treat headache [12]. It is also used in treatment of jaundice, high fever and purgative [13]; stomach ache and gastritis [14]; cirrhosis and hepatitis [15]. Its antifungal [16] and antimicrobial effects has also been established. Moreover, continuous use of the synthetic anti-diabetic drugs causes side effects and toxicity [17]. Antioxidants such as thiols or ascorbic acid (vitamin $\mathrm{C}$ ) terminate chain reactions. To balance the oxidative state, plants and animals maintain complex systems of overlapping antioxidants, such as glutathione and enzymes (e.g., catalase and superoxide dismutase), produced internally, or the

Copyright: $\odot$ The authors. This article is open access and licensed under the terms of the Creative Commons Attribution License (http://creativecommons.org/licenses/by/4.0/) which permits unrestricted, use, distribution and reproduction in any medium, or format for any purpose, even commercially provided the work is properly cited. Attribution - You must give appropriate credit, provide a link to the license, and indicate if changes were made. 
dietary antioxidants vitamin A, vitamin C, and vitamin E [18]. Free radicals produced in the body during normal metabolic functions or introduced from the environment are highly reactive species $[19,20]$. Free radicals contribute to more than 100 disorders in humans including atherosclerosis, arthritis, ischemia and reperfusion injury of many tissues, central nervous system injury, gastritis, cancer. The body possesses defense mechanisms like enzymes and antioxidant nutrients, which arrest the damaging properties of reactive oxygen species [21, 22]. The continuous exposure to chemicals and contaminants may lead to an increase in the amount of free radicals in the body, beyond its capacity to control them, and can cause irreversible oxidative damage [23], that is why exogenous antioxidant especially from plants are very crucial. This present study is designed to evaluate the antioxidant properties and antidiabetic effect of ethanol extract of Garcinia kola.

\section{MATERIAL AND METHODS}

\section{Plant Material}

Fresh fruits of Garcinia kola were bought from Ndolu market in umudike and identified at the plant science and biotechnology department in Micheal Okpara University of Agriculture. The seeds were peeled, chopped and air dried so as to reduce the moisture content. The dried pulp was blended and the powdered samples were stored in polythene bags and placed at room temperature until they were used.

\section{Preparation of plant extract}

Five grams $(5 \mathrm{~g})$ of powdered samples were weighed in separate extraction bottle and $100 \mathrm{ml}$ of solvent (ethanol) was added to the bottle containing the powdered sample and left to stand for 48hours to allow for extraction at room temperature. Thereafter, each solution was filtered using a Whatman filter paper (No.1). The filtrates was concentrated over a water bath $\left(45^{\circ} \mathrm{c}\right)$ and the extract was stored in an airtight container in a refrigerator until required for use [24].

\section{ANIMALS}

Thirty six (36) adult albino rats (110-145g) were obtained from the Laboratory Animal House of the department of Veterinary Physiology and Pharmacology, Michael Okpara University of Agriculture, Umudike. The animals were maintained in a well-ventilated room under $12 \mathrm{~h}$ light: dark cycle and were acclimatized for 2 weeks before the start of the experiment. Animals were given commercial vital pelleted feed and water ad libitum. All the experimental procedures used in this study were performed in accordance with Animal welfare and the Institutional Animal Ethics.

\section{INDUCTION OF EXPERIMENTAL DIABETES MELLITUS}

Diabetes mellitus was induced using the method of Lenzen [25].

\section{EXPERIMENTAL DESIGN}

The albino rats that recorded an elevated blood glucose concentration above $240 \mathrm{~g} / \mathrm{dL}$ were randomly assigned into six groups (A-F) of six rats $(n=6)$ each as follows:

Group A: received distilled water and served as normal control group,

Group B: Alloxan induced diabetic rats which received $5 \mathrm{mg} / \mathrm{kg}$ Gilbenclamide and served as positive control group,

Group C: Alloxan induced diabetic rats (untreated) and served as the negative control group.

Groups D: Alloxan induced diabetic rats treated with $500 \mathrm{mg} / \mathrm{kg}$ of the Garcinia kola extract

Group E: Alloxan induced diabetic rats treated with $250 \mathrm{mg} / \mathrm{kg}$ of the Garcinia kola extract

Group F: Alloxan induced diabetic rats treated with $125 \mathrm{mg} / \mathrm{kg}$ of the Garcinia kola extract

The study lasted for a period of seven days.

\section{DETERMINATION OF BLOOD GLUCOSE LEVELS}

The modified method of Beach and Turner, [26] based on the glucose oxidase principle was adopted in the determination of blood glucose concentration of the experimental rats. The blood samples were collected by cutting the tip of the tail artery of the rats, and a drop allowed to touch the sensor part of one touch glucose strips in Accuk chek glucometer. The values obtained were recorded in $\mathrm{mg} / \mathrm{dl}$. The blood glucose concentration was sampled at intervals of before induction, day 1 , day 3 and day 7 of treatment, respectively.

\section{DETERIMINATION OF ANTIOXIDANTS}

\section{Assay of DPPH Scavenging Activity}

2,2-diphenyl-1-purythydrazine (DPPH) scavenging activity was quantified in the presence of stable DPPH radical using a method used by Singh et al. [27].

\section{Assay of Lipid Peroxidation Scavenging Activity}

The determination of anti-lipid peroxidation activity was done by using the ethanol extract of Garcinia kola at different concentrations $(12.5 \mathrm{mg}, 25 \mathrm{mg}, 50 \mathrm{mg}, 100 \mathrm{mg})$ individually as described by Ohkwa et al. [28].

\section{Nitric Oxide Inhibition Activity}

The nitric oxide scavenging activity was conducted based on the Greiss assay method. 


\section{STATISTICAL ANALYSIS}

All the data are expressed as mean \pm SEM. Statistical comparisons were performed by one-way analysis of variance (ANOVA) using SPSS vision 20.0 followed by Duncan's multiple range tests to separate the mean. The results were considered statistically significant at $\mathrm{p}<0.05$.

\section{RESULT AND DISCUSSION}

The results showed that the treatment groups were significantly $(\mathrm{p}<0.05)$ reduced in a dose dependent manner compared to the negative control group. There was significant $(\mathrm{p}<0.05)$ increase in the negative control compared to the normal.

The results above showed significant $(\mathrm{p}<0.05)$ increase in percentage reduction of increased blood glucose in the treated group compared to the negative control.

\section{DISCUSSION}

This study evaluated the folkloric claim that G. kola seed can be used to reduce the blood glucose level of diabetic patients. Diabetes mellitus is among the most common disorder in developed and developing countries [29]. The disease is increasing rapidly in most parts of the world [30]. Hyperglycaemia in diabetic patients is associated with alterations in glucose and lipid metabolism and modification in liver enzyme levels [31]. Despite the presence of known anti diabetic medicines in the pharmaceutical market, screening for new anti-diabetic sources from natural plants remains the best alternative because they contain substances which are safer for use on diabetes mellitus [9].

In this study, Diabetes was induced in rats by a single intraperitoneal injection of alloxanmonhydrate at $150 \mathrm{mg} /$ $\mathrm{kg}$ body weight. Alloxan is a cytotoxic agent known to induce diabetes in a wide variety of animal species by damaging insulin secreting $\beta$-cell, resulting in decrease of endogenous insulin release, which paved the way for the decrease utilization of glucose by the tissues which leads to increases blood glucose level [25]. The findings of this study indicate that administration of seed extract at the graded dosage used, on alloxan-induced diabetic rats caused a significant $(\mathrm{P}<0.05)$ reduction of the elevated glucose level (anti-hyperglycemic effect). The extract from the seed of Garcinia kola caused a significant maximum decrease of about $50.32 \%$ at the extract dose of $500 \mathrm{mg} / \mathrm{kg}$ in blood glucose concentration as against
$51.96 \%$ for Gilbenclamide after 3 days' treatment and $49.70 \%$ and $45.03 \%$ on day 7 for $500 \mathrm{mg} / \mathrm{kg}$ extract and Gilbenclamide $(5 \mathrm{mg} / \mathrm{kg})$ respectively (Table 1$)$. Also, it was observed that the extract at the various doses studied caused a significant reduction of the blood glucose concentration in a dose dependent manner (Table 2) and this anti-hyperglycemic effect was more pronounced after 3 days' treatment. The propensity of the extract of Garcinia kola to significantly decrease elevated blood glucose levels to almost normal levels is an essential trigger for the liver to return to its normal homeostasis in experimental diabetic rats. This could mean that the anti-hyperglycemic activity of this extract may be partly due to insulin release from the existing cells of the pancreas, stimulation of insulin secretion and release, regeneration of beta cells of Langerhans islets, and/ or activation of enzymes responsible for glucose utilization [32] This finding is not in isolation as it is in agreement with other studies reported by various researchers such as Richards [33]; Adebisi [34]; Srinivasan [35]; Lenzen [25], who evaluated the anti-hyperglycemic potentials of other parts of this medicinal plant.

Radical scavenging activity is very crucial to the survival of living organisms, due to the deleterious role of free radicals in foods and biological systems. There are many methods for evaluating the antioxidant activity of both natural and artificial compounds. Routinely, antioxidant potencies of plants are assessed by their ability to scavenge DPPH, an unstable compound which turns to a stable diamagnetic molecule when protonated. This stability is visually noticeable as a discoloration from purple to golden yellow. The free radical scavenging activity of ethanolic extract of G.kola and also that of ascorbic acid was evaluated through its ability to quench the synthetic DPPH radical. The DPPH assay constitutes a rapid and low cost method that has frequently been used for evaluation of the antioxidative potential of various natural products [36]. The radical scavenging reaction of ascorbic acid with DPPH was essentially instantaneous; the reaction of DPPH with G.kola was also fast but slower compared to that with ascorbic acid. Nitric oxide is a free radical produced in mammalian cells involved in regulation of various physiological processes. However, excess production of nitric oxide is associated with several diseases [37]. The development of substances to prevent the overproduction of nitric oxide has become a new research target for treating chronic inflammatory diseases [38,39]. There is a significant $(\mathrm{p}<0.05)$ dose dependant increase in percentage Nitric oxide inhibition of the plant extract as shown in Table 3. The antilipid peroxidation also showed significant $(\mathrm{p}<0.05)$ dose dependant increase.

Table 1: Percentage reduction on blood glucose concentration $(\mathrm{mg} / \mathrm{dl})$ of albino rats

\begin{tabular}{|c|c|c|c|}
\hline Treatment (mg/kg) & $\begin{array}{c}\text { Percentage protection after } \\
\text { Day } 1(\%)\end{array}$ & $\begin{array}{c}\text { Percentage protection after } \\
\text { Day } 3(\%)\end{array}$ & $\begin{array}{l}\text { Percentage protection after day } \\
\qquad 7(\%)\end{array}$ \\
\hline Normal control & $0.43 \pm 0.73^{c}$ & $0.00 \pm 0.00^{d}$ & $0.00 \pm 0.00^{c}$ \\
\hline Positive control & $7.05 \pm 0.73^{b}$ & $51.96 \pm 11.07^{\mathrm{a}}$ & $45.03 \pm 0.74^{\mathrm{ab}}$ \\
\hline Negative control & $0.00 \pm 0.00^{d}$ & $0.00 \pm 0.00^{c}$ & $0.00 \pm 0.00^{d}$ \\
\hline $500 \mathrm{mg} / \mathrm{kg} \mathrm{G}$. kola seed extract & $15.73 \pm 0.92^{\mathrm{a}}$ & $50.32 \pm 3.58^{\mathrm{a}}$ & $49.70 \pm 0.61^{a}$ \\
\hline $250 \mathrm{mg} / \mathrm{kg} \mathrm{G}$. kola seed extract & $7.74 \pm 0.83^{b}$ & $43.41 \pm 3.08^{b}$ & $43.80 \pm 2.79^{b}$ \\
\hline $125 \mathrm{mg} / \mathrm{kg} \mathrm{G}$. kola seed extract & $7.43 \pm 0.65^{b}$ & $35.52 \pm 6.67^{b}$ & $40.52 \pm 3.31^{b}$ \\
\hline
\end{tabular}

Values are expressed as means \pm SEM in $(\mathrm{mg} / \mathrm{dL})$. Mean value with the same superscript along the same column are not significantly different $(P<0.05)$ 
Table 2: The effect of ethanol extract of Garcinia kola seed on blood glucose concentration ( $\mathrm{mg} / \mathrm{dl}$ ) of albino rats

\begin{tabular}{lccccc}
\hline $\begin{array}{l}\text { Treatment } \\
(\mathrm{mg} / \mathrm{kg})\end{array}$ & $\begin{array}{c}\text { Glucose level }(\mathrm{g} / \mathrm{dL}) \\
\text { before induction }\end{array}$ & $\begin{array}{c}\text { Glucose } \\
\text { level }(\mathrm{g} / \mathrm{dL}) \text { Day 0 }\end{array}$ & $\begin{array}{c}\text { Glucose } \\
\text { level }(\mathrm{g} / \mathrm{dL}) \text { Day 1 }\end{array}$ & $\begin{array}{c}\text { Glucose } \\
\text { level }(\mathrm{g} / \mathrm{dL}) \text { Day 3 }\end{array}$ & $\begin{array}{c}\text { Glucose } \\
\text { level }(\mathrm{g} / \mathrm{dL}) \text { Day } 7\end{array}$ \\
\hline Normal control & $77.33 \pm 0.88$ & $79.00 \pm 1.23$ & $78.66 \pm 0.90$ & $79.00 \pm 1.00$ & $80.12 \pm 0.73$ \\
Positive control & $77.33 \pm 0.88$ & $267.00 \pm 25.23$ & $249.66 \pm 24.90$ & $163.66 \pm 6.00$ & $90.00 \pm 4.04$ \\
Negative control & $75.66 \pm 2.84$ & $262.00 \pm 22.53$ & $379.33 \pm 38.77$ & $500.33 \pm 13.34$ & $560.66 \pm 9.59$ \\
$500 \mathrm{mg} / \mathrm{kg} \mathrm{G}$. kola seed extract & $76.33 \pm 0.33$ & $289.00 \pm 6.92$ & $249.66 \pm 4.48$ & $145.33 \pm 10.65$ & $83.66 \pm 3.28$ \\
$250 \mathrm{mg} / \mathrm{kg}$ G. kola seed extract & $78.33 \pm 0.33$ & $281.00 \pm 13.65$ & $261.00 \pm 14.36$ & $182.00 \pm 9.45$ & $86.66 \pm 2.18$ \\
$125 \mathrm{mg} / \mathrm{kg}$ G. kola seed extract & $77.66 \pm 0.88$ & $284.33 \pm 9.56$ & $264.66 \pm 8.98$ & $196.66 \pm 14.62$ & $116.00 \pm 2.64$ \\
\hline
\end{tabular}

Values are expressed as means \pm SEM in $(\mathrm{mg} / \mathrm{dL})$ with significant level $(P<0.05)$

Table 3: Antioxidant activity of Garcinia kola

\begin{tabular}{lccc}
\hline $\begin{array}{l}\text { Concentration } \\
\text { (mg/ml) }\end{array}$ & $\begin{array}{c}\text { \% DPPH Radical } \\
\text { scavenging activity }\end{array}$ & $\begin{array}{c}\text { \% Anti-lipid } \\
\text { peroxidation }\end{array}$ & $\begin{array}{c}\text { \% Nitric oxide } \\
\text { inhibition }\end{array}$ \\
\hline Vit. C 100 & $76.13 \pm 3.59^{\mathrm{a}}$ & $85.53 \pm 9.24^{\mathrm{a}}$ & $65.67 \pm 3.95^{\mathrm{e}}$ \\
100 & $58.43 \pm 5.03^{\mathrm{b}}$ & $80.80 \pm 3.30^{\mathrm{a}}$ & $50.00 \pm 2.86^{\mathrm{d}}$ \\
50 & $47.57 \pm 5.10^{\mathrm{c}}$ & $65.13 \pm 5.95^{\mathrm{b}}$ & $36.57 \pm 4.86^{\mathrm{c}}$ \\
25 & $33.30 \pm 4.70^{\mathrm{d}}$ & $51.10 \pm 5.53^{\mathrm{c}}$ & $26.50 \pm 8.34^{\mathrm{b}}$ \\
12.5 & $14.90 \pm 4.83^{\mathrm{e}}$ & $26.43 \pm 9.51^{\mathrm{d}}$ & $11.10 \pm 1.93^{\mathrm{a}}$ \\
\hline
\end{tabular}

Values are expressed as means \pm SEM in $(\mathrm{mg} / \mathrm{dL})$. Mean value with the same superscript along the same column are not significantly different $(P<0.05)$. There is a significant $(p<0.05)$ dose dependant increase in all the assay

\section{CONCLUSION}

G. kola seed extract has anti-diabetic activity which is comparable to the standard drug (Gilbenclamide) in alloxan induced diabetic rats and hence maybe a good alternative in the treatment of diabetes. G. kola seed also possess antioxidant properties and could serve as free radical inhibitors or scavengers.

\section{REFERENCES}

1. World Health Organization. Diabetes Fact sheet. Archived from the original on 31 March 2014. Retrieved 4 April 2014

2. Kitabchi AE, Umpierrez GE, Miles JM, Fisher JN. Hyperglycemic crises in adult patients with diabetes. Diabetes Care. 2009; 32(7): 1335-43.

3. Shi Y, Hu FB (June 2014). The global implications of diabetes and cancer. Lancet. 383; (9933): 1947-8.

4. World Health Organization -WHO. (2013)."Diabetes Fact sheet $N^{\circ} 312$ "WHO. October 2013. Archived from the original on 26 August 2013. Retrieved 25 March 2014.

5. Vos T, Flaxman, A.D, Naghavi M, Lozano R, Michaud C, Ezzati M, et al. (December 2012). Years lived with disability (YLDs) for 1160 sequelae of 289 diseases and injuries 1990-2010: a systematic analysis for the Global Burden of Disease Study 2010. Lancet. 380 (9859): 2163-96.

6. Shoback DG, Gardner D. Greenspan's basic and clinical endocrinology (9th ed.). 2011. McGraw-Hill Medical.

7. Ncube NS, Afolayan AJ, Okoh Al. Assessment techniques of antimicrobial properties of natural compounds of plant origin: current methods and future trends. African Journal of Biotechnology, 2008; 7(12):1797-1806.

8. Uko OJ, Usman A, Ataja AM. Some biological activities of Garcinia kola in growing rats. Vetinary Archives, 2001; 71: 287-297.

9. Alli-Smith YR, Adanlawo IG. Hypoglycaemic effect of saponin from the root of garcinia kola (bitter kola) on alloxan-induced diabetic rats. Journal of Drug Delivery \& Therapeutics, 2012; 2(6): 9-12.

10. Braide, VB, Vitrotio G. Histological alterations by a diet containing seeds of Garcinia kola: Effects on liver, kidney and intestine in the rat. Gedenhaurs Morphjol, 1989; 5:95-101.

11. Adesina SK, Gbile ZO, Odukoya OA. Survey of indigenous plants of West Africa with special emphasis on medicinal plants and issues associated with management. The United Nations Programme on Natural Resources in Africa; 2nd edition. 1995; 84-5.

12. Ayensu ES. Medicinal Plants of West Africa, Reference Publ. Inc: Algonac, Michigan. 1978; 162.

13. Iwu MM, Igboko OA, Okunji CO, Tempesta MS. Antidiabetic and aldose reductase activities of Biflavanones of Garcinia kola. Journal of Pharmacy and Pharmacology, 1990; 42: 290-292.

14. Ajebesone PE, Aina JO, Potential African substitutes for hops in tropical beer brewing. Journal of Food Technology in Africa, 2004; 9: 13-16

15. Okwu DE, Phytochemicals. Vitamins and mineral contents of two Nigeria medicinal plants. International Journal of Molecular Medicine and Advance Sciences, 2005; 1: 375-381.

16. Okwu DE, Morah FN. Minerals and nutritive value of Dennrttia tripetala fruits. Friuts, 2004; 59: 437-442

17. Luo Q, Yan YCJ, Sun M, Corkeb H. Hypoglycemic and hypolipidemic effects and antioxidant activity of fruit extracts from Lyciumbarbarum. Life Sciences, 2004; 76: 137-149

18. Tebekeme, $\mathrm{O}$. In vitro antioxidant and free radical scavenging activities of Garcinia kola seeds. Food and Chemical Toxicology.2009; 47 (10): 2620-2623.

19. Ames BN, Shigenaga MK, Hagen TM. Oxidants, antioxidants, and the degenerative diseases of aging. Proceedings of the National Academy of Sciences of the United States of America, 1993; 90:7915 e7922.

20. Harman D. Free radical theory of aging: the "free radical diseases. Age, 1984; 7:111-131.

21. Halliwell B, Aeschbach R, Lologer J, Aruoma OI. The characterization of antioxidants. Food and Chemical Toxicology, 1995; 33:601-617.

22. Sies H. Strategies of antioxidant defense. European Journal of Biochemistry, 1993; 215:213-219.

23. Tseng TH, Kao ES, Chu CY, Chou FP, Lin W, Wang CJ. Protective effects of dried flower extract of Hibiscus sabdariffa L. against oxidative stress in rat primary hepatocytes. Food and Chemical Toxicology, 1997; 35:1159 e1164.

24. Unegbu CC, Ajah O, Amaralam EC, Anyanwu OO. Evaluation of phytochemical contents of Emilliacoccinea leaves. Journal of Medicinal Botany, 2017; 1:47-50.

25. Lenzen, S. The mechanism of alloxan and streptozotocin-induced diabetes. Diabetologia, 2008; 51:216-226.

26. Beach EF, Turner JJ. An enzymatic method for glucose determination in body fluids. Clinical Chemistry, 1958; 4(6):462-475.

27. Singh RP, Murthy KNC, Jayaprakasha GK. Studies on antioxidant activity of pomegranate (Punica granatum) peel and seed extracts using in vitro models. Journal of Agricultural and Food Chemistry, 2002, 50:81-86.

28. Ohkawa, H.S., Ohishi, N., Yagi, K. Assay of Lipid peroxidation in animal tissue by thiobarbituric acid reaction. Analytical Biochemistry, 1979; 95: 351- 358

29. Makund H, Rao CM, Srinivasan KK, Mamathadevi DS, Satish H, Hypoglycemic and hypolipidemic effects of Strobilanthesheyeneanus in alloxan induced diabetes rats. Pharmacognosy Magazine, 2008; 15: 819-824

30. Kumar, A., R. Ilavarasan, T. Jayachandran, M. Deecaraman, P. Aravindan, N. Padmanabhan and hypolipidemic effects of Strobilanthesheyeneanus in alloxan induced diabetes rats. Pharmacognosy Magazine, 2008; 15: 819-824.

31. Jenson T, Stender DT. Abnormalities in plasma concentration of lipoprotein and fibrinogen in type 1 (insulin dependent) diabetic patients with increased urinary albumin excretion. Diabetology, 1998; 31: $142-145$ 
32. Spasov AA, Maxeiner MP Bulanov AE. Antidiabetic properties of Gymnemasylvestre. Pharmaceutical Chemistry Journal, 2008; 42(11): 626-629.

33. Richards AJ. Studies in Garcinia, dioecious tropical forest trees. Botanical Journal of the Linnean Society, 1990; 10(3): 233-250.

34. Adebisi AA. A Case Study of Garcinia kola Nut Production- toConsumption System in $\mathrm{J} 4$ area of Omo Forest Reserve, South -West Nigeria. In: Forest Products, Livelihoods and Conservation: Case Studies on Non-Timber Forest System Sunderland, T. and O. Ndoye (Eds). CIFOR,Bogor, Indonesia, 2004; 2:1-24.

35. Srinivasan K. Plant foods in the management of diabetes mellitus: spices as beneficial antidiabetic food adjuncts. International Journal of Food Sciences and Nutrition, 2005; 56(6): 399-414.

36. Sanchez-Moreno C. Review: method used to evaluate the free radical scavenging activity in foods and biological systems. Food Science and Technology International, 2002; 8:121-137.

37. Ohkawa H, Ohishi H, Yagi K. Assay for lipid peroxide in animal tissues by thiobarbituric acid reaction. Analytical Biochemistry, 1979; 95:351-358.

38. Nathan $C$. Nitric oxide as a secretory product of mammalian cells. FASEB journal, 1992; 6:3051-3064.

39. Shen SC, Lee WR, Lin HY, Huang HC, ChKo Yang LL. In vitro and in vivo inhibitory activities of rutin, wogonin, and quercetin on lipopolysaccharide-induced nitric oxide and prostaglandin E(2) production. European Journal of Pharmacology, 2002; 446:187-194. 